\title{
Theoretical Approach to Study the Nature and Structure of Organotin (IV) Derivatives
}

\author{
Fatma M. Abdul-Hameed \\ Department of Chemistry, College of Science, Al-Nahrain University, Baghdad-Iraq.
}

\begin{abstract}
A theoretical study of semi-empirical calculation of PM3 level was used to characterize three Tin complexes $\left(\mathrm{R}_{2} \mathrm{SnL}_{2}\right)$ [where $(\mathrm{R})$ : (Phenyl), (butyl) and (methyl) and L: (N-tolyl -mmethoxybenzo hydroxamic acid) ]. The comparison of the three complexes that have different (R) had been done on the basis of calculated energies and physical properties of the molecular model systems, such as heat of formation, HOMO-LUMO gap, binding energy, dipole moment, surface area. This present study revealed a clear picture and useful information about the nature of complex stability of the three Tin complexes $\mathrm{R}_{2} \mathrm{SnL}_{2}$. [DOI: 10.22401/JUNS.21.1.05]
\end{abstract}

Keywords: AM1 method, Tin complexes, charge transfer complex.

\section{Introduction}

Tin (IV) and organo-tin(IV) synthesis are fully known by their pose in chemical matier cultivation and other field of epidermal activities [1-3]. There is deceptively modest area of metal (organic and inorganic) chemistry, have been extradite more attentiveness due to the substantial matier and ecological implementation [4]. The organ tin (IV) complexes compounds with oxygen and nitrogen granter ligand have been extensive study not driven only through their coordination chemistry is interesting but also due to the possible implementation in the field of science material, biological action ,cultivation, pharmaceutical chemistry $[5,6]$, potential antineoplastic and anti-tuberculosis agents [7], and cytotoxicity [8] as well as their industrial and agricultural applications [9-12]. Leading of ( $\mathrm{Sn})$ atom to the forming of five membered ring chelate (Oh.) geometry was suggested for complexes prepared [13].

Seeing that the varied field of implementations or oregano tin complexes, we have study theoretically of ligand(L) [(N-Tolylm-methoxybenzohydroxamic) ] and its organo-tin(IV) syntheses Di methyl tin(IV) bis (N- tolyl-m-methoxy benzohydroxamate) (F1), Di butyl tin(IV) bis (N- methyl-m-methoxy benzohydroxamate) (F2), Di phenyl tin(IV) bis (N- tolyl-m-methoxy benzohydroxamate) (F3).[13]

Theoretical-study in gas-phase was completed by method using semi - empirical in order to show the most stable conformation [14]. The aims of research to calculate the formation of heat and energy binding to all suggested-geometries, in orderto determine and evaluate the most active sites for the three Tin complexes $\mathrm{R}_{2} \mathrm{SnL}_{2}$ by using the electrostatic potential calculations. In addition, semi-empirical method was used to calculate dipole moment, surface area and finally bond lengths for all molecular modeling system of Tin complexes $[15,16]$.

\section{Computational Methods}

All molecular structures were optimized completely by application method semiempirical as proceed in the program packing Hyper chem. 7.1 (Hyper cube Inc [17]. GainvilleFL) by using default gradient methods. Hyper chem. offers Ten (IV) semi empirical orbital molecular tichniques, together with choices of organic all major group synthesis for metal transition complexes and simulation spectral [15]. Choose from parameterization model version3 (PM3), [including metals transition]. (PM3) were hired for the computation of formation heat, energy binding, Frontier Orbital Energies (HOMO, and LUMO) and other parameters for all suggested molecular modeling system of Tin complexes [18-20].

\section{Results and Discussion}

The program Hyperchem is included the semi-empirical with PM3 level and molecular mechanics with amber method for obtaining optimized geometries of molecular modeling system in gas phase at the ground state [ $\left.Y^{\prime}\right]$. The result of calculations was formation of 
heat $\left(\Delta \mathrm{H}_{\mathrm{f}}^{\mathrm{O}}\right)$ and energy binding $\left(\Delta \mathrm{E}_{\mathrm{b}}\right)$ for ligand and its complexes $\mathrm{R}_{2} \mathrm{SnL}_{2}$ which are listed in Table (1). The data of Table (1) depicted that the stability of Tin complexes follow the order: F2>F1>F3.

Table (1)

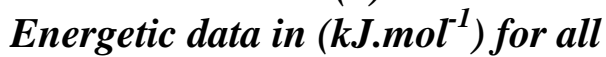
components of $\mathrm{R}_{2} \mathrm{SnL}_{2}$.

\begin{tabular}{|c||c|c||c|}
\hline Molecule & $\Delta \boldsymbol{H}_{\boldsymbol{f}}$ & Total energy & $\Delta \boldsymbol{E}_{\boldsymbol{b}}$ \\
\hline \hline L1 & -8.466 & -16823.564 & -878.456 \\
\hline \hline F1 & 27.8718 & -346876.196 & -1885.933 \\
\hline \hline F2 & 18.144 & -40823.433 & -2290.533 \\
\hline \hline F3 & 54.3237 & -42728.696 & -2318.167 \\
\hline
\end{tabular}

The molecular optimized structure of most stable conformations are shown in Fig.(1). The six coordination number is completed by two carbons at one of $(\mathrm{R})$. Since the all component of $\mathrm{R}_{2} \mathrm{SnL}_{2}$ are concerning and diverge only in subrogate $(\mathrm{R})$ group, it seems that the stability of complexes reflected by the effect of (R) group to obtain the more stable conformations.

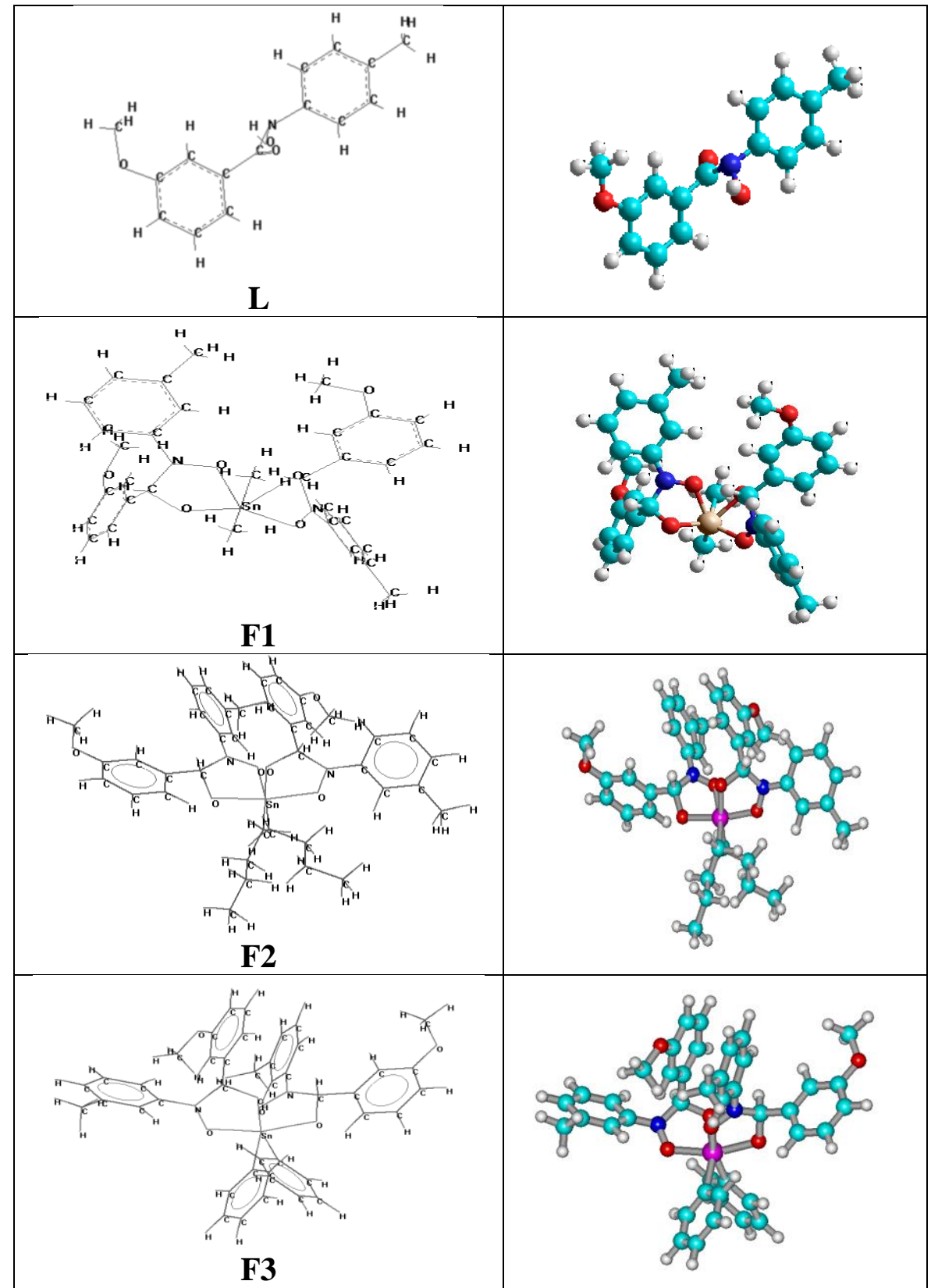

Fig.(1): Optimized molecular structure of all component of $\mathrm{R}_{2} \mathrm{SnL}_{2}$. 
Potential Electrostatic (E.P) of electron allocation judged potential the electrostatic of molecules, and also delineate interaction of the system molecular with a formal charge positive [22]. So it of use for find a site of reaction a molecule charged positive setting tend to attack a molecule where the E.P is strongly negative electro philic offensive. E.P of ligand free was studied and conspired as $2 \mathrm{D}$ contour for discuss the sites active of molecule Fig.(2). It is clear that Fig.(2) gave a whole view for the electrostatic potential of the ligand and the electrostatic potential of complexes $\mathrm{R}_{2} \mathrm{SnL}_{2}$ had differed due to the rearmament of electron distribution over the each complex.

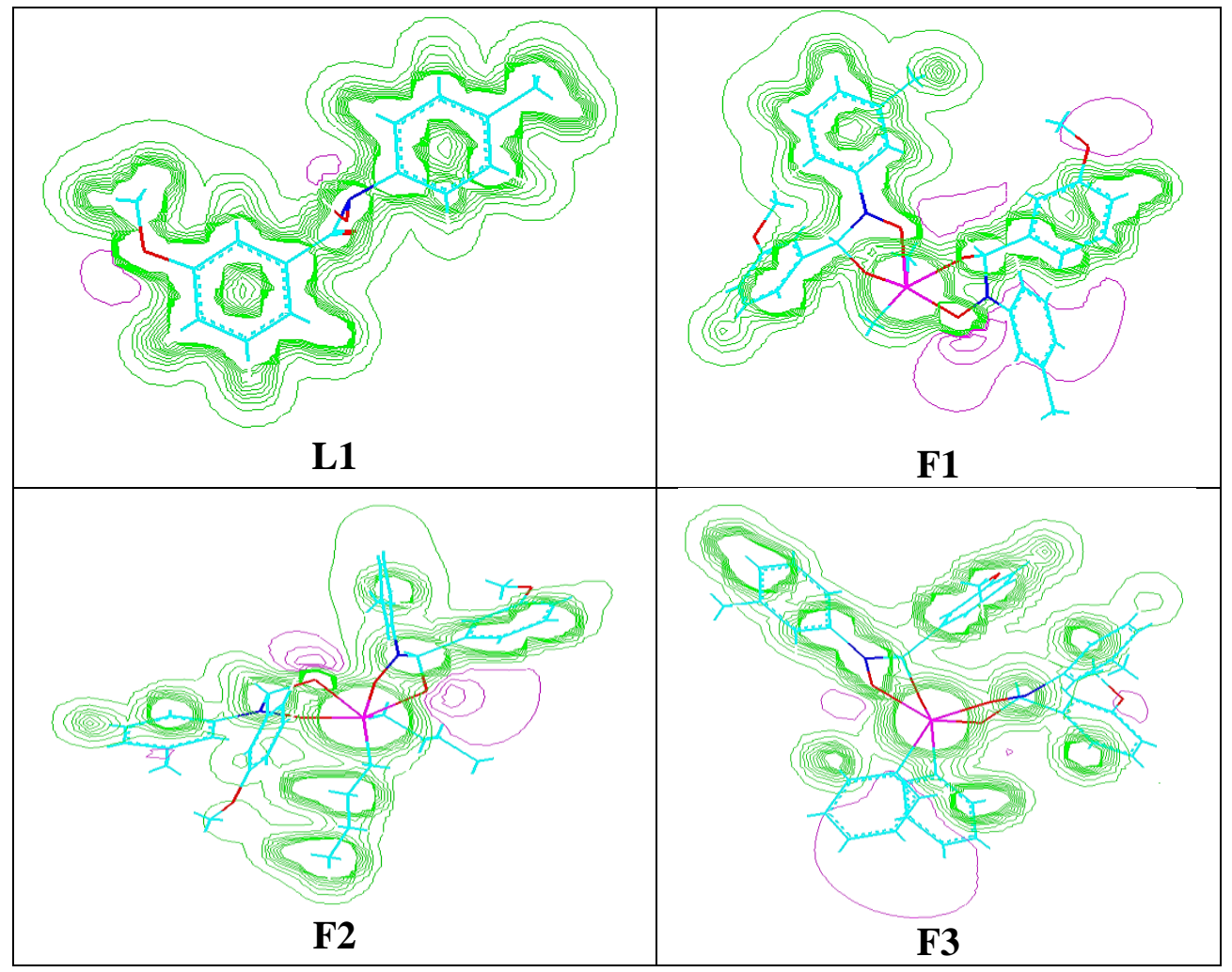

Fig.(2): Electrostatic potential (E.P) as 2D of all compounds.

Molecular orbital accounts submitted an energetic description of the orbitals including the spatial characteristics model patterns and single atom contribution. Frontier Energies Orbital of top of an occupied molecular orbital (HOMO) and the least part is not occupied molecular orbital (LUMO) are listed in Table (2). The contour plots of border orbits for the state ground of all component of $\mathrm{R}_{2} \mathrm{SnL}_{2}$ complexes shown in Fig.(3).
Table (2)

Frontier Orbital Energies (HOMO, LUMO) (in Ev).

\begin{tabular}{|c||c||c|c||}
\hline Molecule & HOMO & LUMO & HOMO-LUMO gap \\
\hline \hline L1 & -9.327 & - & -9.23378 \\
\hline \hline F1 & -6.677 & -3.176 & -3.176 \\
\hline \hline F2 & -6.541 & -3.331 & -3.21 \\
\hline \hline F3 & -7.169 & -3.972 & -3.197 \\
\hline
\end{tabular}


The HOMO-LUMO gap data in Table (2) is in consistency with the stability order of three $\mathrm{R}_{2} \mathrm{SnL}_{2}$ complexes with $\mathrm{F} 2>\mathrm{F} 1>\mathrm{F} 3$. In addition, Fig.(3) revealed that high electron density of frontier Orbital HOMO is focused on donating atoms of suggested molecular modeling system of Tin complexes.

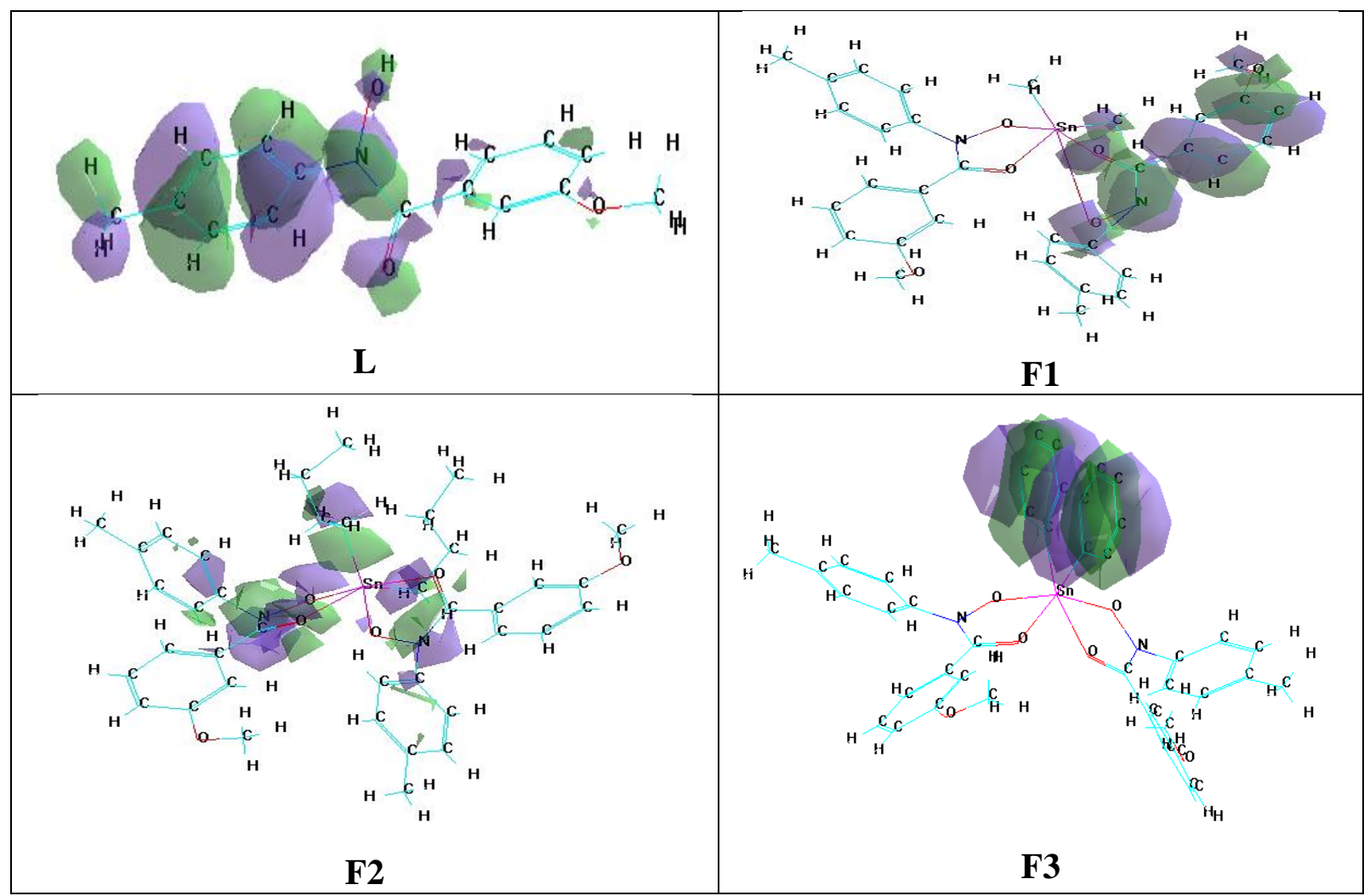

Fig.(3): HOMO and LUMO as $3 D$ of all compounds.

Also, the lower value in the HOMO and LUMO power gap would explain in the end charge transfer the interaction that occurs in side molecular model systems [23]. In Table (3) set forth Infrared-Spectroscopic study of all compounds that are favorite practically, theoretically and mistake percentage. The Fig.(4) shows the calculate bond lengths of the all compounds (L, F1, F2 and F3).

In quantitative structure-property relationships (QSPR) design, forecasts are made up of physic-chem. characteristics or theoretical molecular descriptors of chemicals. QSPR is involving in Hyperchem software and the results of calculations are listed in Tables (3-6). The data in Tables $(1,2)$ is in consistency with the stability order of three $\mathrm{R}_{2} \mathrm{SnL}_{2}$ complexes with the results of tables $(\varepsilon-V)$. 
Table (3)

Comparison of experimental and theoretical vibration frequencies.

\begin{tabular}{|c|c|c|c|c|c|c|}
\hline Symb. & $v(\mathrm{O}-\mathrm{H})$ & $v(C=O)$ & $v(C-N)$ & $v(\mathrm{~N}-\mathrm{O})$ & $v(S n-C)$ & $v(S n-O)$ \\
\hline L1 & $\begin{array}{l}\text { rYOI* } \\
3900 * * \\
19.9 * * *\end{array}$ & $\begin{array}{c}1617 * \\
1930^{* *} \\
19.3^{* * *}\end{array}$ & $\begin{array}{c}1429 * \\
1278^{* *} \\
-10.2 * * * \\
\end{array}$ & $\begin{array}{r}953 * \\
959^{* *} \\
0.62 * * * \\
\end{array}$ & - & - \\
\hline $\mathrm{F} 1$ & - & $\begin{array}{c}197 \% * \\
10 \gamma \mu * * \\
-7.08 * * *\end{array}$ & $\begin{array}{c}1430 * \\
1588 * * \\
11.04 * * *\end{array}$ & $\begin{array}{c}934 * \\
996 * * \\
6.63 * * *\end{array}$ & $\begin{array}{c}545^{*} \\
550^{* *} \\
1.83^{* * *}\end{array}$ & $455^{*}$ \\
\hline $\mathrm{F} 2$ & - & $\begin{array}{r}1691^{*} \\
1816^{* *} \\
7.39^{* * * *} \\
\end{array}$ & $\begin{array}{c}1428 * \\
1337 * * \\
-6.37 * * * \\
\end{array}$ & $\begin{array}{c}927 * \\
991 * * \\
6.9 * * * \\
\end{array}$ & $\begin{array}{r}573 * \\
591^{* *} \\
3.1^{* * *} \\
\end{array}$ & $\begin{array}{c}454^{*} \\
512^{* *} \\
12.77^{* * *} \\
\end{array}$ \\
\hline F3 & - & $\begin{array}{l}1724 * \\
1687 * * \\
-2.1 * * *\end{array}$ & $\begin{array}{c}1442 * \\
1362 * * \\
-5.54 * * * \\
\end{array}$ & $\begin{array}{l}922 * \\
904 * * \\
-1.95\end{array}$ & $\begin{array}{c}569^{*} \\
545^{* *} \\
-4.2^{* * *} \\
\end{array}$ & $\begin{array}{c}443^{*} \\
519^{* *} \\
17.1^{* * *} \\
\end{array}$ \\
\hline
\end{tabular}

Where:

*: Experimental frequency

**: Theoretical frequency

***: Error\% due to main difference in the experimental measurements and theoretical treatment of vibration spectrum.

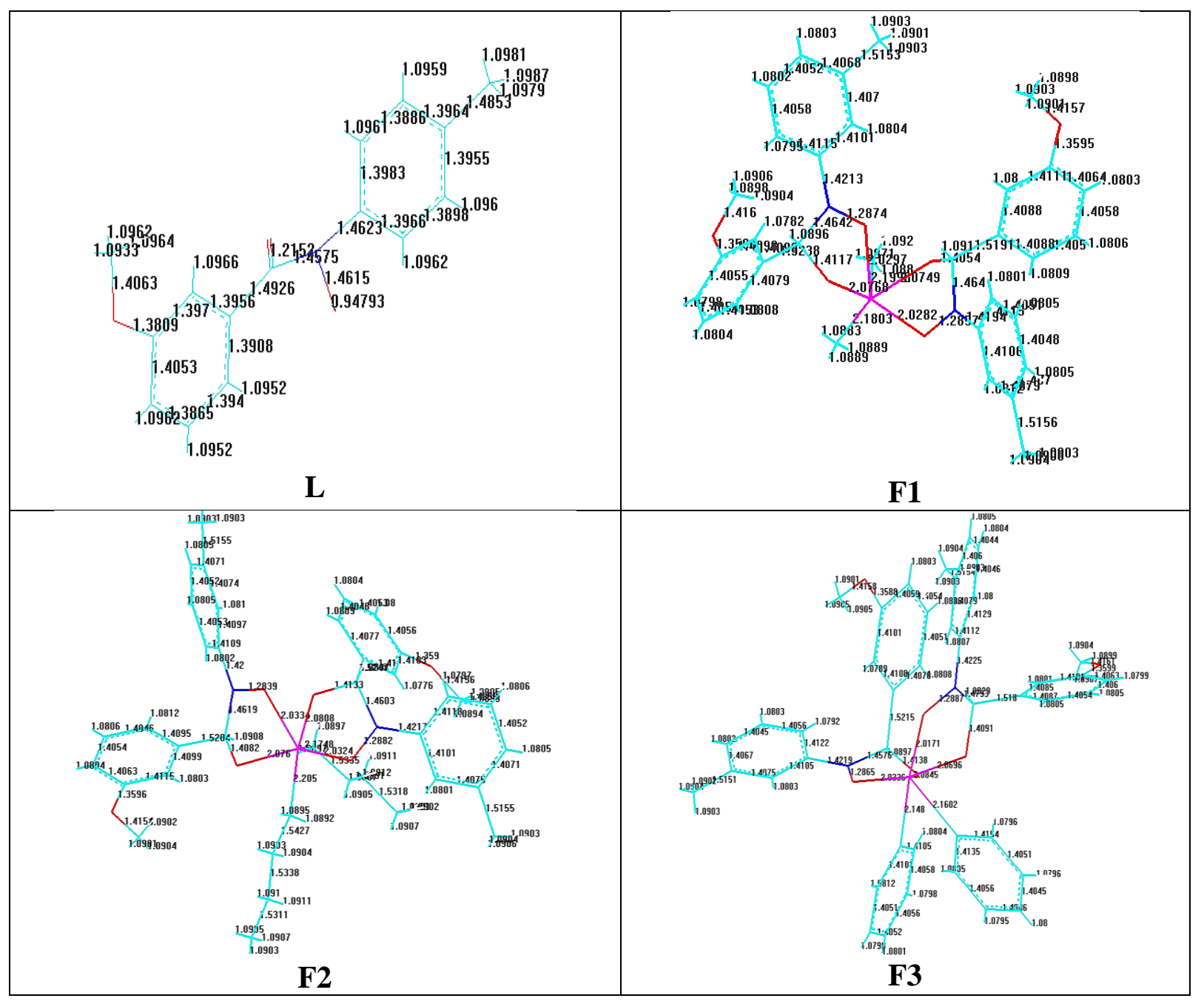

Fig.(4): Bond lengths of compounds. 
Table (4)

Molecular properties and QSAR properties of $L$.

\begin{tabular}{|c|c|c|}
\hline 1. & Total Energy & $-16823.564(\mathrm{~kJ} / \mathrm{mol})$ \\
\hline 2. & Binding Energy & $-878.456(\mathrm{~kJ} / \mathrm{mol})$ \\
\hline 3. & $\begin{array}{l}\text { Isolated Atomic } \\
\text { Energy }\end{array}$ & $-66650.5562850(\mathrm{kcal} / \mathrm{mol})$ \\
\hline 4. & Electronic Energy & $\begin{array}{l}-459585.9429265 \\
(\mathrm{kcal} / \mathrm{mol})\end{array}$ \\
\hline 5. & $\begin{array}{l}\text { Core-Core } \\
\text { Interaction }\end{array}$ & $\begin{array}{l}389263.5238957 \\
(\mathrm{kcal} / \mathrm{mol})\end{array}$ \\
\hline 6. & Heat of Formation & -8.466 (kJ/mol) \\
\hline 7. & Gradient & $0.0970670(\mathrm{kcal} / \mathrm{mol} / \mathrm{Ang})$ \\
\hline 8. & Surface area & 239.6 \\
\hline 9. & Volume & $799.73 \mathrm{~A}^{03}$ \\
\hline 10. & Dipole moment & $2.466 \mathrm{D}$ \\
\hline 11. & Surface area $($ Grid $)$ & $495.74\left(\mathrm{~A}^{02}\right)$ \\
\hline 12. & $\begin{array}{l}\text { Surface area } \\
\text { (approx) }\end{array}$ & $439.12\left(\mathrm{~A}^{02}\right)$ \\
\hline 13. & "Hydration energy & $-8.68(\mathrm{kcal} / \mathrm{mol})$ \\
\hline 14. & Log p & 3.51 \\
\hline 15. & Refractivity & $72.30\left(\mathrm{~A}^{03}\right)$ \\
\hline 16. & Polarizability & $28.31\left(\mathrm{~A}^{03}\right)$ \\
\hline 17. & Mass & $257.29(\mathrm{amu})$ \\
\hline 18. & Nuclear Energy & $38979.43(\mathrm{kcal} / \mathrm{mol})$ \\
\hline 19. & Net Charge & $0.00 \mathrm{e}$ \\
\hline 20. & RMS & $0.09175(\mathrm{Kcal} / \mathrm{mol})$ \\
\hline 21. & HOMO & $-9.327(\mathrm{ev})$ \\
\hline 22. & LUMO & $-0.09322(\mathrm{ev})$ \\
\hline
\end{tabular}

Table (5)

Molecular properties and QSAR properties of $F 1$.

\begin{tabular}{|c||l||l||}
\hline 1. & Total Energy & $-346876.196(\mathrm{~kJ} / \mathrm{mol})$ \\
\hline \hline 2. & Binding Energy & $-1885.933(\mathrm{KJ} / \mathrm{mol})$ \\
\hline 3. & $\begin{array}{l}\text { Isolated Atomic } \\
\text { Energy }\end{array}$ & $-142059.3575160(\mathrm{kcal} / \mathrm{mol})$ \\
\hline \hline 4. & Electronic Energy & $\begin{array}{l}-1442767.3460422 \\
\mathrm{kcal} / \mathrm{mol})\end{array}$ \\
\hline \hline 5. & $\begin{array}{l}\text { Core-Core } \\
\text { Interaction }\end{array}$ & $1292661.2523975(\mathrm{kcal} / \mathrm{mol})$ \\
\hline \hline 6. & $\begin{array}{l}\text { Heat of } \\
\text { Formation }\end{array}$ & $27.8718(\mathrm{~J} / \mathrm{mol})$ \\
\hline \hline 7. & Gradient & $-47.0301288(\mathrm{kcal} / \mathrm{mol})$ \\
\hline 8. & Surface area & 537.32 \\
\hline \hline 9. & Volume & $1732.50\left(\mathrm{~A}^{03}\right)$ \\
\hline \hline 10. & Dipole moment & $9.714(\mathrm{D})$ \\
\hline \hline 11. & $\begin{array}{l}\text { Surface area } \\
(\text { Grid })\end{array}$ & $922.58\left(\mathrm{~A}^{02}\right)$ \\
\hline \hline 12. & $\begin{array}{l}\text { Surface area } \\
\text { approx })\end{array}$ & $860.36\left(\mathrm{~A}^{02}\right)$ \\
\hline \hline 13. & Hydration energy & $-10.62(\mathrm{Kcal} / \mathrm{mol})$ \\
\hline \hline 14. & Log p & 7.61 \\
\hline \hline 15. & Refractivity & $154.38\left(\mathrm{~A}^{03}\right)$ \\
\hline 16. & Polarizability & $64.45\left(\mathrm{~A}^{03}\right)$ \\
\hline \hline 17. & Mass & $663.34(\mathrm{amu})$ \\
\hline \hline 18. & Nuclear Energy & $1453906.3(\mathrm{Kcal} / \mathrm{mol})$ \\
\hline \hline 19. & Net Charge & $0.00(\mathrm{e})$ \\
\hline 20. & RMS grid & $0.0974(\mathrm{Kcal} / \mathrm{mol})$ \\
\hline \hline 21. & HOMO & $-7.304606(\mathrm{ev})$ \\
\hline 22. & LUMO & $-3.643403(\mathrm{ev})$ \\
\hline \hline
\end{tabular}

Table (6)

Molecular properties and QSAR properties of F2.

\begin{tabular}{|c|c|c|}
\hline 1. & Total Energy & $-40823.433(\mathrm{~kJ} / \mathrm{mol})$ \\
\hline 2. & Binding Energy & $-2290.533(\mathrm{~kJ} / \mathrm{mol})$ \\
\hline 3. & $\begin{array}{l}\text { Isolated Atomic } \\
\text { Energy }\end{array}$ & $\begin{array}{l}-161067.5251320 \\
(\mathrm{kcal} / \mathrm{mol})\end{array}$ \\
\hline 4. & Electronic Energy & $\begin{array}{l}-1951076.3423094 \\
(\mathrm{kcal} / \mathrm{mol})\end{array}$ \\
\hline 5. & $\begin{array}{l}\text { Core-Core } \\
\text { Interaction }\end{array}$ & $\begin{array}{l}1780282.7827173 \\
(\mathrm{kcal} / \mathrm{mol})\end{array}$ \\
\hline 6. & Heat of Formation & $18.144(\mathrm{~kJ} / \mathrm{mol})$ \\
\hline 7. & Gradient & "0.0889641 (kcal/mol/Ang) \\
\hline 8. & Surface area & 638.95 \\
\hline 9. & Volume & $2000.26\left(\mathrm{~A}^{03}\right)$ \\
\hline 10. & Dipole moment & $6.116(\mathrm{D})$ \\
\hline 11. & Surface area (Grid) & $1058.10\left(\mathrm{~A}^{02}\right)$ \\
\hline 12. & $\begin{array}{l}\text { Surface area } \\
\text { (approx) }\end{array}$ & $1041.41\left(\mathrm{~A}^{02}\right)$ \\
\hline 13. & Hydration energy & $-5.32(\mathrm{Kcal} / \mathrm{mol})$ \\
\hline 14. & $\log \mathrm{p}$ & 10.03 \\
\hline 15. & Refractivity & $182.12\left(\mathrm{~A}^{03}\right)$ \\
\hline 16. & Polarizability & $75.49\left(\mathrm{~A}^{03}\right)$ \\
\hline 17. & Mass & $747.50(\mathrm{amu})$ \\
\hline 18. & Nuclear Energy & $178263.625(\mathrm{Kcal} / \mathrm{mol})$ \\
\hline 19. & Net Charge & $0.00(\mathrm{e})$ \\
\hline 20. & RMS & $0.1005(\mathrm{Kcal} / \mathrm{mol})$ \\
\hline 21. & HOMO & -6.541 \\
\hline 22. & LUMO & -3.331 \\
\hline
\end{tabular}

Table (7)

Molecular properties and QSAR properties of F3.

\begin{tabular}{|c|c|c|}
\hline 1. & Total Energy & $-42728.696(\mathrm{~kJ} / \mathrm{mol})$ \\
\hline 2. & Binding Energy & $-2318.167(\mathrm{~kJ} / \mathrm{mol})$ \\
\hline 3. & $\begin{array}{l}\text { Isolated Atomic } \\
\text { Energy }\end{array}$ & $\begin{array}{l}-168916.0136280 \\
(\mathrm{kcal} / \mathrm{mol})\end{array}$ \\
\hline 4. & Electronic Energy & $\begin{array}{l}-2090228.5758124 \\
(\mathrm{kcal} / \mathrm{mol})\end{array}$ \\
\hline 5. & $\begin{array}{l}\text { Core-Core } \\
\text { Interaction }\end{array}$ & $\begin{array}{l}1911419.8934860 \\
(\mathrm{kcal} / \mathrm{mol})\end{array}$ \\
\hline 6. & Heat of Formation & $54.3237(\mathrm{~kJ} / \mathrm{mol})$ \\
\hline 7. & Gradient & $\begin{array}{l}0.0963155 \\
\text { (kcal/mol/Ang) }\end{array}$ \\
\hline 8. & Surface area & 651.57 \\
\hline 9. & Volume & 1977.76 \\
\hline 10. & Dipole moment & 7.267 \\
\hline 11. & Surface area (Grid) & $1016.29\left(\mathrm{~A}^{02}\right)$ \\
\hline 12. & $\begin{array}{l}\text { Surface area } \\
\text { (approx) }\end{array}$ & $903.36\left(\mathrm{~A}^{02}\right)$ \\
\hline 13. & Hydration energy & $-10.59(\mathrm{Kcal} / \mathrm{mol})$ \\
\hline 14. & Log $\mathrm{p}$ & 10.98 \\
\hline 15. & Refractivity & $193.93\left(\mathrm{~A}^{03}\right)$ \\
\hline 16. & Polarizability & $80.10\left(\mathrm{~A}^{03}\right)$ \\
\hline 17. & Mass & 787.48(amu) \\
\hline 18. & Nuclear Energy & $1928784.75(\mathrm{Kcal} / \mathrm{mol})$ \\
\hline 19. & Net Charge & $0.00(\mathrm{e})$ \\
\hline 20. & RMS & $0.08833(\mathrm{Kcal} / \mathrm{mol})$ \\
\hline 21. & HOMO & -7.169 \\
\hline 22. & LUMO & -3.972 \\
\hline
\end{tabular}




\section{Conclusion}

Theoretical quantum calculations for all suggested molecular modeling system of Tin complexes $\mathrm{R}_{2} \mathrm{SnL}_{2}$ have successful results to give useful information about of physicochemical properties and energetic data to predict the optimum conformations of Tin complexes $\mathrm{R}_{2} \mathrm{SnL}_{2}$.

\section{References}

[1] Davies A.G.; Ssmith P.J.; "Tin in comprechensire orqanometalic chemi stone and ew abel (oxford; press)", 2, 519, 1982.

[2] Smith P. J.; "Chemistry of tin (London. Blackie academic and professional )" $2^{\text {nd }}$ end, 1997.

[3] Garima M. and Robina A.; "Tin-and organotin (IV) complexes of thymol derivative derived from alanine: synthesis and characteristic spectral studies", Rasayan J. Chem., 4,3, 594- 598, 2011

[4] Tammy L. and Georges M.; "New applications of LC-MS and LC-MS2 toward under standing the environmental fat of organometallics", Trends in analytical chemistry, 24, 7-12, 2005.

[5] Jason H.; Kieran C. and Pratt R.; "Inhibition of serine amidohydrolasea by complexes of vanadate with hydroxamic acid”. Bio chemical and biophysical res. Communications, 274: 732-735, 2000.

[6] Mohammed M.; Khadija S.; Shoal M.; Saqib A. and Maoazzam B.; "Synthesis, Spectral Characterization and Biological Applications of Tri- and Diorganotin(IV) Derivatives of 2-[N- (2,6-Dichloro-3methylphenyl)amino]benzoic acid", Turkish journal of chemistry , 28, 17- 26, 2004.

[7] Yousif E.; Adil H.; Majeed M.; Farina Y.; "Synthesis, characterization and fungicidal activity of some diorganotin (IV) with 2thioacetic-5- phenyl-1,3,4-oxadiazole", .J. Fundam. Sci.5 (2), 94-98, 2009.

[8] Gielen M.; "Organotin compounds and their therapeutic potential: a report from the organometaiiic chemistry department of the free university of Brussels, a review, applied organometallic chemistry", 16(9), 481- 494, 2002.
[9] Thoonen S.; Deelman B.; Koten G.; "Synthetic aspects of tetraorganotins and organotin (IV) halides", journal of organometallic chemistry, 689, 2145- 2157 , 2004.

[10] Katosoulakou E.; Tiliakos M.; Papaefstathiou G., Terzis A.; Raptopoulou C.; Geromichalos G.; Papazisis K.; Papi R.; Pantazaki A.; Kyriakidis D.; Cordopatis P.; Zoupa E.; "Diorganotin(IV) complexes of dipeptides containing the aaminoisobutyryl residue (Aib): preparation structural characterization antibacterial and antiproliferative activities of $(\mathrm{n}-\mathrm{Bu}) 2 \mathrm{Sn}(\mathrm{H}-$ IL)(LH=H- Aib- L-Leu -OH,H-Aib-L-Alo$\mathrm{OH})$ ", Journal of inorganic biochemistry, 102, 1397-1405, 2008.

[11] Sandhu G.K.; GuptaR.; Sandhu S.S.; Parish R.V.; Brown K.; "Diorganotin(IV) derivatives of $\mathrm{N}$ - phthaloyl amino acids", Journal of organometallic chemistry, 279, 373- 384, 1985.

[12] Nowell I.W.; Brooks J.S.; Beech G., Hill R.; "Crystal and molecular structure of dimethylchlorotin 2- pyridinecarbooxylatc", J. Organomet. Chem.; 244, 119-124, 1983.

[13] Abdualbasit G.; Yang F.; Emad Y.; Elhadi E. Saad; "Organotin(IV) Derivatives of N-Tolyl-m- methoxybenzohyroxamic Acid:Synthesis and structural Elucidation", International J. of Chemistry,1,2, 34-47, 2009.

[14] Fried L.H. and Souers P.; “CHEETAH 2.0 Users Manual, Lawrence Livermore National Laboratory", (1999).

[15] Foresman J. and Frish C.; "Exploring Chemistry with Electronic structure Methods" $2^{\text {nd }}$ ed.;Gaussian Inc.; Pittsburgh; PA., (1996).

[16] MOPAC 2000 maunal; J.J.J. Stewart. Fujitsu. limited, (1999).

[17] Hyper Chem, version 7.5, z Hypercube, Inc.: Gainesville, FL, USA, 2002.

[18] Chem 3D 3.5 User manual; Cambridge Soft; MA, 1996.

[19] Mehdi S. Shiahab; "Study of solvent Effects in Diels-Alder reaction through Charge Transfer formation by using semiempirical calculations", J. Bull. Korean Chem. Soc. Vol.29, No.10, 1898- 1904, 2008. 
[20] Mehdi S. Shiahab; "Am1 Semi- empirical calculation study the nature of di and trimolecular assembly of $\pi, \pi$-aromatic interactions", The Arabian J. for Science and Engineering, 35, 2A, 95-113, 2009.

[21] Ban A. Abd-al-Jabbae, "preparation of som organic compounds contain heteroatoms as corrosion inhibiters for mild steel in acidic media", 2013.

[22] Anderson W. P.; Behm P. and Glennon T. M.; "Quantum Mechanics and Molecular Mechanics studies of the Low-Energy conformations of 9-corown-3", J. Phys. Chem. , A, 101, 1997.

[23] Har L. S., Jangbhadur S., Suresh S. C., Mukherjee A. and Tejpal D., "Synthetic, structural, theoretical and biological study of triorganotin (IV) Schiff base complexes derived from amino acids", J. Chemical and Pharmaceutical Research, 6(11), 248- 257, 2014. 